\title{
First report of foliicolous fungus Trichothecium roseum (Pers.) Link on sweet cherry Prunus avium L. from Kashmir Valley
}

\section{Nadia Ashraf*, Mohd Yaqub Bhat and Abdul Hamid Wani}

University of Kashmir. Department of Botany. Section of Mycology and Plant Pathology. Kashmir - 190006. India."Email: nadiaashraf70@gmail.com.

\begin{abstract}
Cherry Prunus avium L. is an important cash crop of Kashmir Valley. Cherry leaves are attacked by number of foliicolous fungi which in turn reduce yield of crop. Severe leaf spots were observed on cherry leaves in an orchard of district Baramulla of Kashmir Valley. These spots were similar to those caused by Blumeriella jaapii but smaller in size. Pathogenicity tests were conducted using detached leaf technique. Re isolation of spores from inoculated leaves confirmed Trichothecium roseum as causative agent of purple leaf spot of cherry. This is the first report of Trichothecium roseum responsible for leaf spot of cherry in Kashmir Valley.
\end{abstract}

Keywords: Cash crop; Cherry; Leaf spot; Yield; Foliicolous.
Received

July 10, 2020

Accepted

August 28, 2020

Released

August 31, 2020

Full Text Article

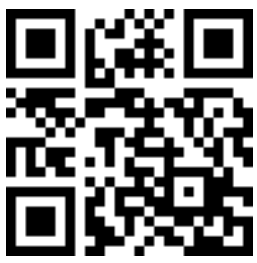

(D) 0000-0002-7272-4564

Nadia Ashraf

D 0000-0002-0582-4813

Mohd Yaqub Bhat

(D) 0000-0002-6157-9656

Abdul Hamid Wani

\section{Introduction}

Cherry belongs to Family Rosaceae and Subfamily Prunoideae. It is cultivated in all the major temperate regions of the world. In India cherry is mainly cultivated in Jammu and Kashmir and to some extent in parts of Himachal Pradesh and Uttar Pradesh. Total area under cultivation of cherry in Jammu and Kashmir during 2012-2013 was 3.75 ha (Anonymous, 2012). Export of cherry from Jammu and Kashmir earns a handsome foreign exchange. Foliicolous fungi cause significant damage to the yield of cherry. Initially small 
light purple spots $4 \mathrm{~mm}-5 \mathrm{~mm}$, appear on upper surface of leaves that later on merge to form blotches (Figure 1a).
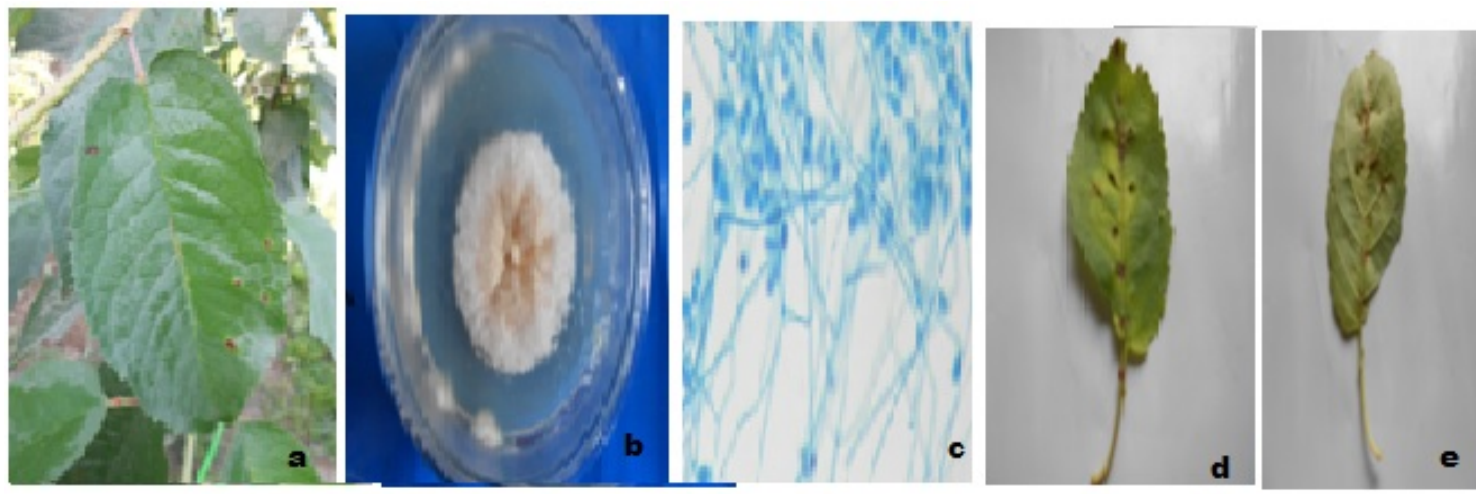

Figure 1. a. Infected leaves of Cherry; b. Culture of Trichothecium roseum on PDA. c. Trichothecium roseum: Mycelium with conidia (100x). d and e. Pathogenicity test on detached leaves (in vitro).

These blotches are of various shapes. Early infection begins from mid June. There is too much similarity in the symptoms of Trichothecium leaf spot and Blumeriella leaf spot with some minute differences. In the former small round purple spots appear on upper surface of leaves only while as in latter round purple spots appear on upper surface of leaves followed by red or white spots on lower surface of leaves.

\section{Material and method}

\section{Survey and preliminary examination}

A survey of an orchard of District Baramulla of Kashmir Valley was conducted in June-July 2019 to study the foliicolous fungus associated with severe cherry leaf spot. During the survey, infected leaf samples of cherry were collected in clean polythene bags and brought to laboratory. Preliminary examination of the collected specimen was done by sectioning method in which thin sections of leaf spots were cut with sterilized blade. These were then mounted on slide containing a drop of cotton blue in lactophenol and observed under compound microscope.

\section{Isolation and Cultural examination}

Fungi have diverse nutritional requirements (Cochrane, 1958). In order to obtain the maximum growth and sporulation of present fungus, four different culture media VIZ: Potato dextrose agar (PDA), Czapek Dox Agar (CDA), Modified Czapek Dox Agar and Host decoction + Agar media, were used. Infected leaf portions (about $5 \mathrm{~mm}$ x $5 \mathrm{~mm}$ ) were cut, surface sterilized with $1 \%$ sodium hypochlorite for 2 min. These leaf bits were then washed in double distilled water, placed on Potato Dextrose Agar medium containing streptomycin sulphate $(250 \mu \mathrm{g} / \mathrm{mL}$ of medium $)$ and incubated at $24{ }^{\circ} \mathrm{C} \pm 2{ }^{\circ} \mathrm{C}$ for 8 days. Same process was repeated for other three media. The pathogen produced maximum radial growth on Potato Dextrose Agar (PDA) medium followed by Czapeks Dox Agar (CDA), Modified Czapeks Dox Agar and Host decoction+Agar media. While as maximum sporulation was found on Host decoction + Agar medium followed by PDA, Modified CDA and CDA media (Figuras 2f, $g$ and $\mathrm{h}$ ). 

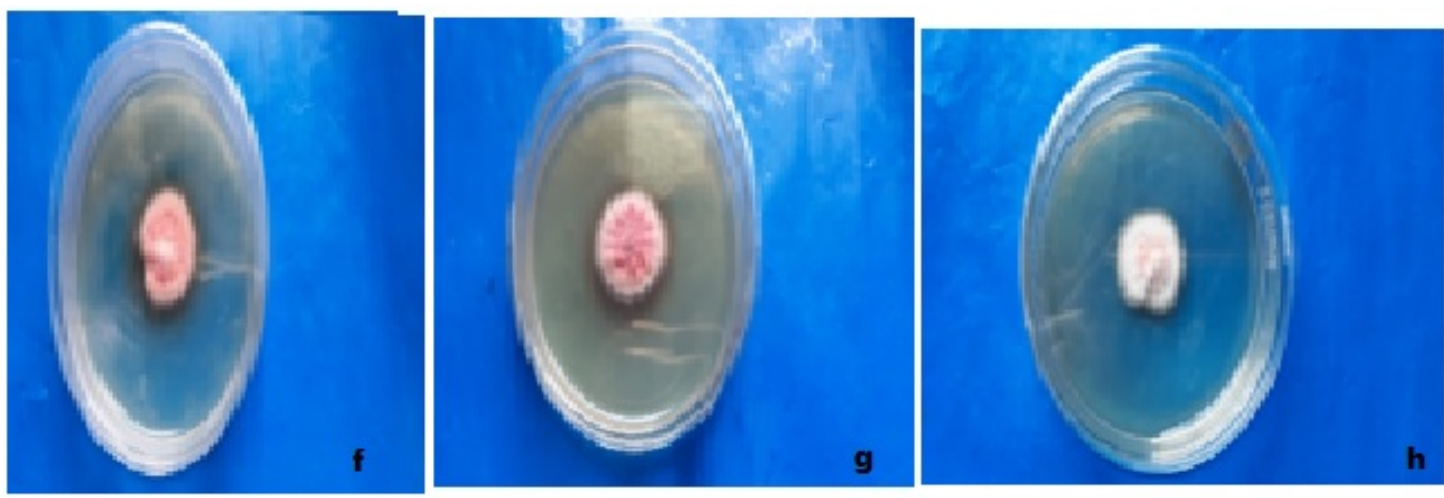

Figure 2. f, g and h. Culture of T.roseum on CDA, Modified CDA and Host decoction + agar media.

Table 1. Sporulation, morphology and mycelial growth of Trichothecium roseum on various media.

\begin{tabular}{|l|l|l|c|}
\hline Media used & Sporulation & \multicolumn{1}{|c|}{ Colony morphology } & $\begin{array}{c}\text { Average Mycelial } \\
\text { radial growth (mm) }\end{array}$ \\
\hline PDA & +++ & Circular, powdery, pinkish & $31.33^{*}$ \\
\hline CDA & + & Circular, smooth, peachy & 30.13 \\
\hline Modified CDA & ++ & Circular, smooth, peachy & 29.46 \\
\hline Host decoction + Agar & ++++ & Circular, smooth, pinkish & 27.23 \\
\hline
\end{tabular}

++++ Very good; +++ Good; ++ Poor; + Very poor. *Mycelial growth in triplicates

\section{Microscopic examination}

Microscopic study revealed that mycelium is well developed, branched, hyaline and septate. Conidiophores are hyaline, straight, smooth, $144 \mu \mathrm{m}$ x $3.0 \mu \mathrm{m}-4.5 \mu \mathrm{m}$, bearing conidia in zigzag manner. Conidia are bi-celled, pyriform, smooth, light pink colored, $4 \mu \mathrm{m}-10 \mu \mathrm{m} \times 12 \mu \mathrm{m}-19 \mu \mathrm{m}$. These were the characteristics similar to that of $T$. roseum (Figure 1c). The fungus was identified on the basis of cultural and microscopic characteristics through monographs and diagnostic keys. For further authenticity pure cultures were sent to ICAR New Delhi.

\section{Pathogenicity test}

Pathogenicity of fungus was conducted to confirm Koch's postulates by using 'detached leaf technique' (Satishkumar, 1994). In this method detached leaves with petiole inserted in $5 \%$ water agar were inoculated with spore suspension $\left(5 \times 10^{4}\right.$ conidia/mL $)$ and then incubated at $24{ }^{\circ} \mathrm{C} \pm 1{ }^{\circ} \mathrm{C}$ (Aneja, 1996). Control leaves were not inoculated instead treated with distilled water. Symptoms similar to that observed in the field conditions were noticed after 7 days in inoculated leaves (Figure $1 \mathrm{~d}$ and e). However, control leaves remained symptomless. Upon re-isolation of fungal spores from inoculated leaves similar fungal colonies were obtained. Pathogenicity tests were conducted twice under same conditions.

\section{Discussion and conclusion}

Trichothecium roseum fungus is mostly saprophytic or weakly parasitic and has been mainly found associated with rot. In India Trichothecium roseum has been reported as a rot fungus by many workers. There are only a few reports of Trichothecium 
responsible for leaf spot from Kashmir Valley. Trichothecium kashmeriana sp. nov. has been reported on leaves of Pyrus malus L. and other Trichothecium sp. have been reported on leaves of Berginia ciliata Wall and Rosa alba L. from Kashmir Valley (Dar, 2017). Besides infecting cherry leaves, Trichothecium roseum has been found to infect leaves of other hosts such as mango, cherry laurel (Bernadovičová and Ivanová, 2011; Shilan et al., 2011). To our knowledge this is the first report of Trichothecium roseum causing leaf spot on cherry leaves from Kashmir Valley. This study will prove beneficial for the management of causative pathogen. However, further study is needed to work on other aspects of this pathogenic fungus Trichothecium roseum.

\section{Acknowledgement}

Authors are highly indebted to the Head, Department of Botany, University of Kashmir, for providing necessary facilities for the successful accomplishment of this work.

\section{Conflicts of interest}

Authors declare that they do not own any conflicts of interest.

\section{References}

Aneja, K. R. Experiments in microbiology, phytopathology, tissue culture and mushroom production technology. 3. ed. New Delhi: New Age International, 2001.

Anonymous. Area under cultivation of fruits in Jammu and Kashmir. Directorate of Horticulture, Marketing and Produce, Government of Jammu and Kashmir, 2013.

Bernadovičová, S.; Ivanová, H. Hyphomycetes and Coelomycetes fungi isolated from infected leaves and twigs of cherry laurel trees. Folia Oecologica, v. 38, no. 2, p. 137-145, 2011.

Cochrane, V. W. Physiology of fungi. Ney York: John Wiley \& Sons, 1958.

Dar, R. A. Foliicolous mycoflora of South Kashmir: A mycotaxonomic study. Sagar: Dr. Harisingh Gour Central University, 2017. (Ph.D. thesis).

Satishkumar, L. Detached leaf bioassay to screen sunflower for Alternaria using the host specific toxin of Alternaria helianthi. Indian Phytopathology, v. 45, no. 11, 1994.

Shilan, H.; Zengliang, L.; Xiaomei, L.; Yixian, X.; Jinji, P. A new disease in Mangifera sp. caused by Trichothecium roseum. Journal of Fruit Science, v. 28, no. 3, p. 474-478, 2011.

License information: This is an open-access article distributed under the terms of the Creative Commons Attribution License, which permits unrestricted use, distribution, and reproduction in any medium, provided the original work is properly cited. 